"Przegląd Prawa Konstytucyjnego" - Nr 1 (17)/2014 -------

\title{
Sprawozdanie
}

\section{Międzynarodowa Konferencja Jesienna Szkoła Prawa Stosowanie prawa (zmiany $w$ procesach internacjonalizacji i europeizacji prawa), Modra-Harmonia, 15-23 listopada 2013 r.}

Od 1996 r. pod auspicjami Instytutu Państwa i Prawa Słowackiej Akademii Nauk realizowana jest idea cyklicznych spotkań prawników z Europy Środkowej, poświęconych wieloaspektowym zagadnieniom z zakresu teorii i praktyki prawa. Przedsięwzięcie kierowane jest do wybranych w procesie rekrutacji absolwentów prawa - zarówno doktorantów, jak i przedstawicieli praktyki prawniczej - a jego celem, poza przekazaniem wiedzy i zapewnieniem możliwości uczestnictwa w dyskusji doktrynalnej, jest także wymiana doświadczeń i nawiązywanie kontaktów, które w przyszłości mogą dać asumpt do poszerzenia zakresu współpracy naukowej i zawodowej.

Tegoroczna XVIII edycja Międzynarodowej Konferencji Jesienna Szkoła Prawa (Modra-Harmonia, 15-23 listopada 2013 r.) została zorganizowana we współpracy z takimi podmiotami, jak: Paneuropejska Wysoka Szkoła w Bratysławie, Friedrich Ebert Stiftung i Slovenský národný podporný výbor EUROPE 2000, jako część większego projektu poświęconego znaczeniu prawa w dynamice rozwoju społecznego. Tematem przewodnim tegorocznej konferencji była problematyka stosowania prawa w kontekście zachodzących procesów internacjonalizacji i europeizacji.

Zebranych powitali główni organizatorzy sympozjum, JUDr. Eduard Bárány, DrSc. oraz mgr Daniela Lengyelova, PhD, którzy w swoim wystąpieniu podkreślili doniosłą rolę uregulowań prawa międzynarodowego i jego wpływu na rozwój ustawodawstwa krajowego, wyrażając przy tym nadzieję, iż szerokie spektrum poruszanej podczas konferencji problematyki pomoże 
zrozumieć wyzwania wynikające z europeizacji i internacjonalizacji, pojawiające się $\mathrm{w}$ praktyce stosowania prawa.

Jako pierwszy prelekcję wygłosił JUDr. František Cvrček, CSc., reprezentujący Instytut Państwa i Prawa Czeskiej Akademii Nauk, w trakcie której dokonał szczegółowej analizy pojęcia „stosowanie prawa” i sposobów jego użycia.

W kolejnym wystąpieniu JUDr. Věra Jirásková, CSc. z Wydziału Prawa Uniwersytetu Karola w Pradze, skupiła swoje rozważania na tematyce konstytucjonalizmu europejskiego w XXI w., poddając pod rozwagę uczestników konferencji kwestię tego, czy wobec intensyfikacji procesów europeizacji i internacjonalizacji konstytucja w dalszym ciągu stanowi fundament państwa czy też przeżytek. Tak postawione pytanie wzbudziło liczne kontrowersje i wywołało gorącą dyskusję uczestników.

Następny dzień konferencji rozpoczęło wystąpienie mgr. Adriána Tokára, PhD., LL.M. - pracownika Komisji Europejskiej w Brukseli, który wygłosił wykład na temat stosowania prawa w Unii Europejskiej, wskazując przy tym na zasadę autonomii prawa unijnego, zarówno względem prawa międzynarodowego, jak i prawa wewnętrznego poszczególnych państw członkowskich. W swoim wystąpieniu prelegent przedstawił praktyczne aspekty zasady supremacji prawa wspólnotowego nad prawami państw członkowskich z punktu widzenia doświadczeń Komisji Europejskiej, wskazując także na problemy powstające w związku ze stosowaniem unijnego prawa, jak i procedurę postępowania w przypadku naruszenia prawa UE przez państwo członkowskie.

W kolejnym wykładzie JUDr. Peter Colotka, PhD., LL.M. z Instytutu Państwa i Prawa Słowackiej Akademii Nauk w Bratysławie, wskazywał na różne możliwości rozumienia pojęcia jurysprudencji, za synonim którego uważa pojęcie teorii prawa. Prelegent podkreślił, iż w jego przekonaniu nauka teorii prawa jest ściśle powiązana z praktycznymi aspektami jego stosowania. Dalsza część wykładu została poświęcona wskazaniu właśnie tych powiązań.

Z dużym zainteresowaniem spotkał się także wykład, który wygłosiła JUDr. Lucia Kurilovská, PhD. z Ministerstwa Sprawiedliwości Republiki Słowackiej. W swoim wystapieniu dr Kurilovská zwróciła uwagę na specyfikę wykładni prawa karnego, wskazując przy tym na poszczególne rodzaje 
wykładni, które następnie umiejętnie przeanalizowała, przechodząc od teorii do praktycznego zastosowania prawa. Znaczną część swojego wykładu poświęciła także problematyce nowelizacji prawa karnego wynikającej z konieczności transponowania norm unijnych.

Problematyką stosowania prawa konstytucyjnego zajął się prof. JUDr. Ján Svák, DrSc., rektor Paneuropejskiej Wysokiej Szkoły w Bratysławie. W swoim wykładzie przedstawił różnice w orzecznictwie Trybunałów Konstytucyjnych Czech i Słowacji. Swoją uwagę koncentrował również na tzw. teście proporcjonalności, którym jest, według Europejskiego Trybunału Praw Człowieka w Strasburgu, stosowanie zasad legalizmu, praworządności i społeczeństwa demokratycznego. Referent sformułował także 33 zasady prawa konstytucyjnego, które omówił na praktycznych przykładach.

Piątego dnia Jesiennej Szkoły Prawa swój wykład na temat metodologi wykładni prawa wygłosił JUDr. Filip Melzer, PhD., LL.M. z Wydziału Prawa Uniwersytetu Palackiego w Ołomuńcu. Wskazał na znaczenie prawnej metodologii, która jego zdaniem powinna być swoistą zaporą przed dowolnością w wyrokowaniu i jednocześnie mostem, który ma zaprowadzić każdego do poznania tego, co jest w konkretnym przypadku w zgodzie z prawem. Prezentowana przez niego koncepcja wskazuje na pytania, które trzeba postawić, zastanawiając się nad tym, co jest zgodne z prawem, jak również jakie fakty należy wziąć pod uwagę przy poszukiwaniu odpowiedzi na te pytania.

Uczestnicy konferencji mieli także okazję wysłuchać prelekcji wiceprzewodniczącego Trybunału Konstytucyjnego Republiki Słowackiej JUDr. Milana Lalíka, który wskazywał na liczne problemy związane ze stosowaniem prawa, pojawiające się na etapie wydawania orzeczeń przez Trybunał Konstytucyjny. W swoim wystąpieniu wskazywał także na stopniowy rozwój słowackiego prawa cywilnego, który pozostaje pod silnym wpływem pierwotnego i wtórnego prawa Unii Europejskiej.

W kolejnym dniu sympozjum swój wykład wygłosił prof. JUDr. Pavel Holländer, DrSc. z Paneuropejskiej Wysokiej Szkoły w Bratysławie. W swojej niezwykle interesującej prelekcji przedstawił koncepcję stosowania prawa jako spiralę hermeneutyczną, łącząc w swojej wypowiedzi, z właściwą dla siebie umiejetnością - prawo, filozofię i sztukę. Prof. Holländer, nawiązując do światowych dzieł artystycznych, wskazał różne sposoby postrzegania pojęć prawa, moralności i sprawiedliwości. 
Ze szczególnym zainteresowaniem spotkał się wykład wygłoszony przez prof. dr hab. Andrzeja Bisztygę - prorektora Górnośląskiej Wyższej Szkoły Handlowej im. Wojciecha Korfantego w Katowicach, który jako jedyny wykładowca reprezentował na tym międzynarodowym forum polskie środowisko naukowe. $Z$ uwagi na szczególne znaczenie omawianej problematyki z punktu widzenia polskiego prawa konstytucyjnego warto poświęcić nieco więcej uwagi na przypomnienie najważniejszych założeń prelekcji.

Meritum wystąpienia prof. Andrzeja Bisztygi zostało poświęcone zagadnieniu interpretacji prawa w orzecznictwie polskiego Trybunału Konstytucyjnego. Prof. Bisztyga dokonał ogólnej charakterystyki polskiego sądu konstytucyjnego, przedstawił zagadnienie zasad naczelnych Konstytucji Rzeczypospolitej Polskiej jako wiodącego tworzywa pracy Trybunału Konstytucyjnego, omówił zagadnienie aktywizmu orzeczniczego sądów, by skoncentrować się na wyrokach interpretacyjnych TK.

W zasadach naczelnych Konstytucji RP, czy szerzej rzecz ujmując - w postanowieniach dwóch pierwszych rozdziałów Konstytucji RP - referent upatruje wielkiej aksjologii naszej konstytucji, rozwijanej przez polską naukę prawa konstytucyjnego oraz orzecznictwo TK. Podejmując zagadnienie aktywizmu orzeczniczego, prof. A. Bisztyga wskazał między innymi na potrzebę wyważania pomiędzy systemowo założoną wiernością literze prawa i wykładni językowej jako wiodącemu rodzajowi wykładni a zabiegami interpretacyjnymi dostosowującymi prawo w toku jego stosowania do wyzwań rzeczywistości i przyszłości. Obok zalet aktywizmu orzeczniczego, ujawnionych zwłaszcza w okresie ustrojowej transformacji kraju, wskazał również na związane z nim zagrożenia, ograniczeniem dla których powinna być zasada sędziowskiej powściągliwości.

Wyroki interpretacyjne to ten rodzaj orzeczeń TK, w których sentencji stwierdza się zgodność bądź niezgodność z konstytucją aktu normatywnego w jego określonym rozumieniu, dodajmy w rozumieniu będącym efektem zabiegu wykładniczego. W takich sytuacjach TK bardziej stwierdza konstytucyjność bądź niekonstytucyjność wyniku wykładniczego przepisu niż konstytucyjność bądź niekonstytucyjność samego przepisu. Wyroki te stanowią przedmiot kontrowersji, a nawet źródło rozbieżności stanowisk Sądu Najwyższego oraz Trybunału Konstytucyjnego wobec nich. Skutkiem tego jest rozdźwięk opinii w tej sprawie dwóch wiodących organów władzy są- 
downiczej: SN i TK. Istotą tego prawoznawczego problemu wydaje się kwestia czytelnego rozróżnienia i wytyczenia wyraźnej granicy między interpretacją prawa a rozstrzyganiem o niekonstytucyjności prawa. To jednak zadanie niełatwe, zważywszy na subtelność materii. Trudno bowiem „wyjałowić” zabieg badania konstytucyjności prawa z wszelkich tych czynności i intelektualnych operacji, które opatrujemy mianem interpretacji. Prof. A. Bisztyga przedstawił wchodzące w zakres wykładu zagadnienia w sposób dynamiczny, przytaczając odpowiednie orzecznictwo TK, co spotkało się z ogromnym zaciekawieniem uczestników konferencji.

Słuchacze Jesiennej Szkoły Prawa mieli także możliwość uczestniczenia w prelekcji JUDr. Jana Bárty, CSc. dyrektora Instytutu Państwa i Prawa Czeskiej Akademii Nauk, która dotyczyła problematyki stosowania prawa administracyjnego. Swoją uwagę skoncentrował na praktycznych problemach, z którymi można zetknąć się podczas stosowania prawa administracyjnego, przy czym nie unikał także odniesienia do kontekstu historycznego. Dr Bárta dokonał porównania procesu stosowania prawa administracyjnego ze stosowaniem prawa w innych dziedzinach; wskazał także na różnice w stosowaniu prawa administracyjnego w Republice Czeskiej i na Słowacji.

Z dużym zainteresowaniem spotkał się także wykład JUDr. Eduarda Bárány’ego, DrSc. z Instytutu Państwa i Prawa Słowackiej Akademii Nauk w Bratysławie, w którym wskazał na różnice i wzajemne zależności między wykonywaniem, stosowaniem a interpretacją prawa. Dr Bárány zwrócił uwagę na fakt, iż jednostka może realizować swoje prawa także w sposób nieświadomy, tj. bez zastosowania procesu wykładni prawa, przy czym należy mieć na względzie, że wykonywanie prawa zawsze ingeruje także w prawa innych osób niż jego adresaci. Referent w swoich rozważaniach zwrócił uwagę na pojęcie sprawiedliwości przy wykonywaniu prawa, podkreślając, iż dla dokonania obiektywnej oceny prawa koniecznym jest odniesienie sie nie tylko do literalnego brzmienia przepisu, ale także wzgląd na proces jego praktycznej realizacji, z tym, że, zdaniem referenta, prawo obroni się przed tym, co jest nierozsądne i niesprawiedliwe.

Kolejnym prelegentem był prof. JUDr. Ján Klučka, CSc. - dyrektor Instytutu Prawa Europejskiego na Wydziale Prawa Uniwersytetu Pawła Józefa Safarika w Koszycach. Przybliżył on uczestnikom konferencji zagadnienia związane z problematyką stosowania międzynarodowego prawa publiczne- 
go. W swoim wystąpieniu szczegółowo omówił kwestie konstytucyjnych regulacji w zakresie pierwszeństwa zastosowania umów międzynarodowych w poszczególnych krajach Europy Środkowej, przedstawiając interesujące orzecznictwo międzynarodowych organów sądowych.

Ostatni dzień Jesiennej Szkoły uświetnił wykład prof. JUDr. Jána Švidroň, CSc. z Instytutu Państwa i Prawa Słowackiej Akademii Nauk w Bratysławie, który został w całości poświęcony tematyce stosowania prawa prywatnego międzynarodowego.

Problematyka poszczególnych wykładów wzbudziła żywe zainteresowanie wśród słuchaczy, o czym świadczyła towarzysząca im dyskusja z prelegentami. Przemyślany dobór tematyki oraz zaproszenie wybitnych specjalistów w poszczególnych dziedzinach prawa z terenu Słowacji, Czech i Polski potwierdzają znaczenie Jesiennej Szkoły Prawa na międzynarodowej arenie.

$\mathrm{Na}$ zakończenie sympozjum w imieniu organizatorów prof. Švidroň podziękował wszystkim uczestnikom, wręczając im certyfikaty potwierdzające ukończenie Jesiennej Szkoły Prawa w 2013 r. Organizatorzy wydarzenia w swoich przemówieniach zaprosili wszystkich uczestników na kolejną edycję, która będzie pierwszym spotkaniem „dorosłego” już przedsięwzięcia, dodając przy tym, iż zaproszenie dotyczy wszystkich zainteresowanych prawników z sąsiednich krajów, którzy posługują się językiem słowackim lub czeskim w stopniu umożliwiającym zrozumienie treści wykładów.

Marta Ołyńska

Vladimír Gajdičiar Uniwersytet Masaryka w Brnie 